レーザー解説

\title{
半導体レーザーの原子の吸収線を用いた波長安定化
}

\author{
佐 藤孝 ${ }^{*}$
}

(1990年 8 月 10 日 受理)

\section{Wavelength Stabilization of a Semiconductor Laser by Using an Atomic Absorption Line}

\author{
Takashi SATO*
}

(Received August 10, 1990)

\begin{abstract}
This paper reviews the oscillation wavelength stabilization of a semiconductor laser using an atomic absorption line that is an accurate and stable wavelength reference. The strong absorption lines of cesium and rubidium atoms have been used as wavelength references for semiconductor laser wavelength stabilization because these lines are in the oscillation wavelength range of a semiconductor laser. A saturated absorption spectroscopy method has been applied to the stabilization because it provides a narrow Doppler free absorption spectrum as the wavelength reference. Wavelength stabilization under high speed modulation is required for coherent optical communication. On the other hand, wavelength stabilization without any frequency modulation is required for application fields which need a narrow oscillation linewidth. The wavelength stabilization using an atomic absorption line satisfies these requirements by using some control electronic circuits and/or magneto-optic effects, i.e., the Zeeman and the Faraday effects.
\end{abstract}

Key Words : Semiconductor laser, Wavelength stabilization, Atomic absorption line, High speed modulation, Magneto-optic effect.

\section{1.はじめに}

半導体レーザーは, 発光効率が良く, 安価で 軽量, 小型かつ高速に直接変調が可能なレー ザーである。しかし䨌囲気温度や注入電流の変 動によりその発振波長が変化するため, 発振波 長が安定で発振幅の狭いより高品質なレーザー 光を得るには, 半導体レーザーそのもの, また はその制御系に若干の工夫が必要となる。こ
の発振波長の安定化は, 現在様々な応用分野に おいて必要とされている。例えば, 最近の光通 信の発展は, コヒーレント光通信による高速・ 大容量通信を目指しているが，そのためには高 速変調時における波長安定化が必要となると考 えられる ${ }^{1,2)}$ 。また, ファイバージャイロ用の 光源としては, 発振幅が狭く, かつ波長が安定 な光源として, 半導体レーザーの発振波長の安 定化が必要となっている3)。 
この波長安定化のために, 半導体レーザーそ のものの内部構造に工夫をしているのが, 分布 帰還型 (DFB) 及び分布ブラッグ反射型 (DBR)の 半導体レーザーである。その他に，注入同期に よる方法や, ファブリ・ペロー共振器などの外 部共振器や原子・分子の吸収線を波長基準とし て用いて発振波長の安定化及び発振幅の狭帯域 化を達成する方法がある ${ }^{4)}$ 。

ここでは，このうち原子の吸収線を用いた半 導体レーザーの波長安定化の原理についてまず 述べる。その後, 飽和吸収分光法を用いたより 良い安定度を得る方法, 高速变調時に打ける安 定化そして無変調で発振幅が狭い状態のままの 安定化について述べる。

\section{2. 半導体レーザーに有用な原子の吸収線}

原子の吸収線は, 従来から色素レーザーの波 長安定化によく用いられてきた ${ }^{5,6)}$ 。これは, 原子の吸収線から, 安定でかつ信号強度が大き い波長基準信号が, 比較的容易に得られるから である。ただ様々な原子の吸収線のうち, 実際 に使用することができるものは非常に少なく， 使用できる原子の吸収線がない場合にはよく分 子の吸収線が用いられている7,8)。これは, 原 子が単体で気体として存在することが, その吸 収線を用いる上で重要であるにもかかわらず， そのような性質を持つ元素が少ないからであ る。その意味では, 気体分子の吸収線は数多く ある。しかしその反面, 気体分子の吸収線はそ の強度が小さく，十分な吸収による雑音の少な い波長基準を得るのが困難な場合が多い。

単原子気体としては, He, Ne, Arなどの希 ガスがある。その他に $\mathrm{Na}, \mathrm{Rb}, \mathrm{Cs}$ などのアル カリ金属元素のように, 密度は非常に小さいが, 室温で単原子気体となるものもあることが知ら れている。特にこのアルカリ金属原子は, 最外 款電子が 1 個だけ存在する水素類似原子であ り，その吸収スペクトルは比較的簡単であるた め, 昔から研究されてきている ${ }^{9)}$ 。そして，ア ルカリ原子の最も強い吸収線は, 微細構造と呼
ばれている 2 つの吸収線 $\mathrm{D}_{1}$ 線と $\mathrm{D}_{2}$ 線からなり, それらは更に超微細構造と呼ばれるいくつかの 吸収線からなることが知られている。

半導体レーザーの発振波長安定化のための波 長基準として用いるには, これら吸収線の波長 が半導体レーザーの発振波長域内にあることが 必要である。そのため, 現在までよく用いられ てきているのは, これらアルカリ原子のうち, $\mathrm{Rb}\left(\mathrm{D}_{1} \text { 線 : } 794.8 \mathrm{~nm}, \mathrm{D}_{2} \text { 線 }: 780.0 \mathrm{~nm}\right)^{10 \sim 12)}$ と $\mathrm{Cs}\left(\mathrm{D}_{2}\right.$ 線：852.1 nm) ${ }^{13)}$ 原子である。しかし今 後, 可視領域で発振する半導体レーザーの開発 が進めば，K $\left(\mathrm{D}_{1}\right.$ 線 : $769.9 \mathrm{~nm} ， \mathrm{D}_{2}$ 線 : 766.5 $\mathrm{nm})^{14)}, \operatorname{Li}(\mathrm{D}$ 線 : $670.8 \mathrm{~nm})$ や Na $\left(\mathrm{D}_{1}\right.$ 線 $: 589.6$ $\mathrm{nm}, \mathrm{D}_{2}$ 線: $589.0 \mathrm{~nm}$ ) 原子などの吸収線も ${ }^{9)}$, 使用されるようになると思われる。

さてRbは自然界に ${ }^{85} \mathrm{Rb}$ と ${ }^{87} \mathrm{Rb}$ の 2 種類の安定 な同位体が7.2:2.8の割合で存在し, 室温 (298 K)では，その気体の原子密度は $2.5 \times 10^{16} \mathrm{~m}^{-3}$ である15)。その吸収線の波長は，それぞれの 同位体により僅かに異なっており， $\mathrm{D}_{2}$ 線を例 にとると，その吸収線は 2 つの同位体に対し,

Fig. 1 (a)に示す相対位置と強度を持った各々 6 本ずつ計 12 本の超微細構造に当たる吸収線で 構成されている ${ }^{16)}$ 。室温では, 原子の熱運動 によるドップラ効果のために，1つずつの吸収 線はドップラ広がりを持ち, 12本の吸収線は近 接した 3 本ずつが互いに重なり合って観測さ れ, 結局, Fig. 1 (a)に示した 4 つの吸収ピー クを示すことになる ${ }^{1)}$ 。Fig. 1 (b) に示す $\mathrm{D}_{1}$ 線 は，2つの同位体に対して各々 4 本ずつ計 8 本 の超微細構造に当たる吸収線で構成されてい る。 $\mathrm{D}_{2}$ 線に比べて超微細構造間の周波数の間 隔は大きく，その結果 ${ }^{85} \mathrm{Rb} ゙$ はやはりドップラ 広がりの中に重なり合って観測されている が， ${ }^{87} \mathrm{Rb} ゙$ は分離されて観測されている。

ドップラ広がりの幅であるドップラ幅 $\Delta_{\mathrm{D}}$ (半 值全幅) は,

$$
\Delta_{\mathrm{D}}=\frac{2 \nu_{0}}{c} \sqrt{\frac{2 \ln 2 k_{\mathrm{B}} T}{M}}
$$

で与えられる。ここでcは光速， $k_{\mathrm{B}}$ はボルッマ 


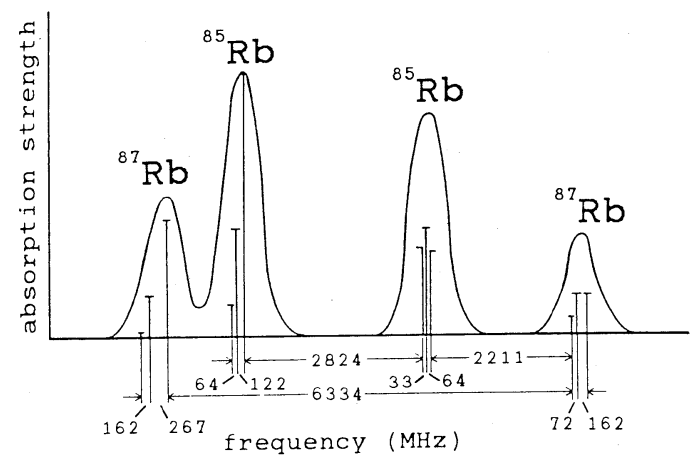

(a)

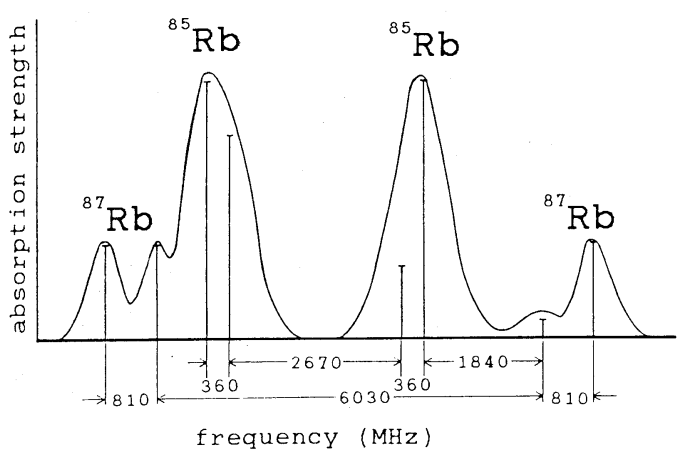

(b)

Fig.1 Relative position, relative intensities and absorption curves of the $R b-D_{2}$ (a) and $D_{1}$ (b) lines.

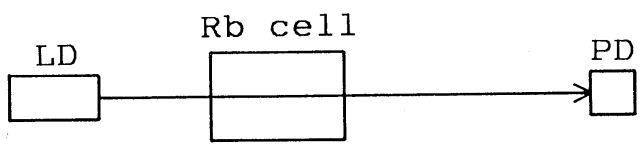

Fig.2 Optical system of linear absorption spectroscopy. LD, laser diode; PD, photo diode.

ン定数, $T$ は気体の絶対温度, $M$ は原子の質量,

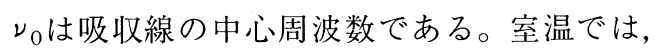
Rb-D線の場合 $\Delta_{\mathrm{D}}$ は約 $500 \mathrm{MHz}$ となる。

\section{3. 原子の吸収線を用いた波長安定化}

次に $\mathrm{Rb}$ 原子の吸収線から波長安定化のため の制御信号を得る原理について述べる。

今, Fig. 2 に示す光学系を用いてRbガス中
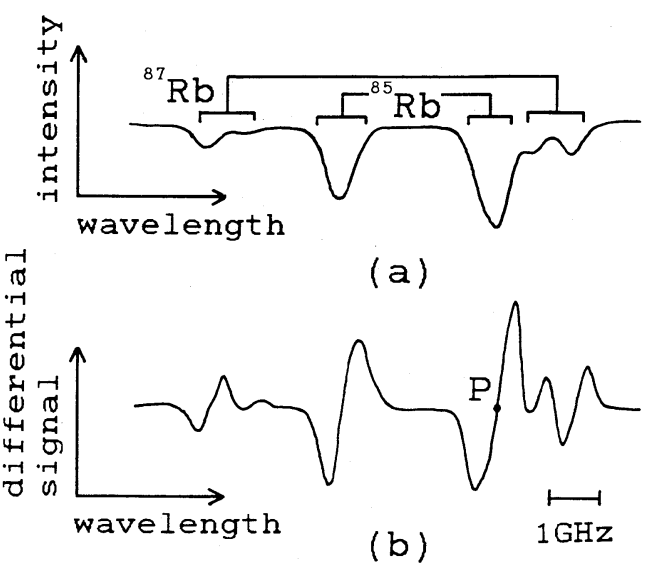

Fig. 3 Absorption profile (a) and the differential profile (b) of $\mathrm{Rb}-\mathrm{D}_{1}$ linear absorption spectroscopy.

を透過する光を観測する場合を考える。透過光 強度は， $\mathrm{D}_{1}$ 線の場合Fig. 3(a)のようになる。 ここでこの光の波長を微小に変調すると, 透過 光強度も変調される。この透過光強度の变調成 分は，その点における透過光強度波形の傾き, すなわち微分值に比例している。従ってこの変 調成分の信号を同期検波すると，Fig. 3 (b) に 示すような周波数に関して 1 次微分された波形 が得られる。この微分波形は, 吸収波形の中心 の最も吸収が強くなる点でゼロとなり, その前 後で符号を変えるので，これを制御信号として 用いて，波長をこの吸収線の中心に安定化する ことが可能となる。この吸収線の中心は外部の 温度変化などにほとんど影響されないので, 非 常に精度の良い波長基準となり得る。一方，透 過光強度信号を基準電圧と比較し, 吸収波形の 傾きが大きい所にゼロ点を持つような信号を得 て，それを制御信号とすることにより，微小変 調を加えない安定化も可能である ${ }^{17)}$ 。この方 法はファブリ・ペロー共振器を波長基準として 用いても報告されている ${ }^{17,18)}$ 。しかし, 吸収 線の傾きを用いる場合には温度変化によるドッ プラ幅の変化や吸収量の変化により, 制御信号 のゼロ点が変動してしまう可能性があるため, 従来から注入電流へ微小な変調を加えることに よりレーザーの発振周波数を微小に変調し, 卡 


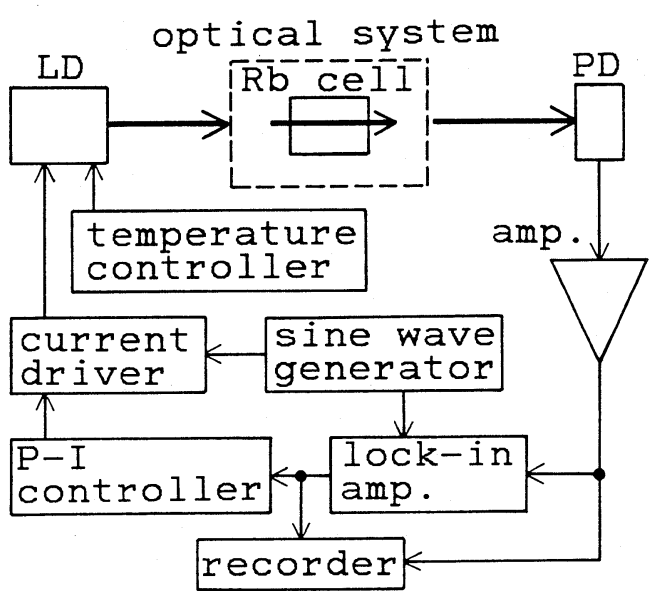

Fig. 4 An example of an experimental setup.

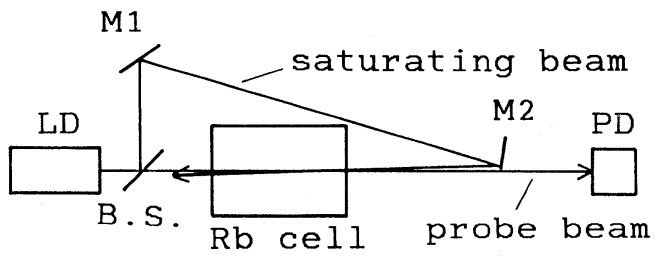

Fig. 5 Optical system of saturated absorption spectroscopy. LD, laser diode ; PD, photo diode; B.S., beam spritter; M1 and M2, mirrors.

こから制御信号を得て波長を安定化する方法の 方がよく採用されている。

Fig. 4 にRb原子の吸収線を用いた半導体 レーザーの波長安定化の実験系の 1 例を示 $す^{12)}$ 。この実験系では，半導体レーザーの注 入電流に微小変調を加えることにより, 半導体 レーザーの発振波長を僅かに变化させている。

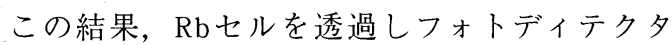
で受光された透過光強度信号を, ロックインア ンプで同期検波することで前述の微分波形が得 られる。Fig. 4 の実験系でFig. 2 に示した光学 系を用いた場合には，ドップラ広がりのため， 近接した超微細構造の個々の吸収線を分解する ことができず，Fig. 3 に示した吸収波形と微分 波形とが観測される。この通常の線形吸収分光 を用いた方法に対し, 光学系としてFig. 5 に示

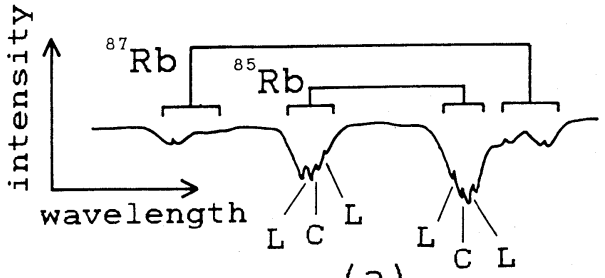

(a)

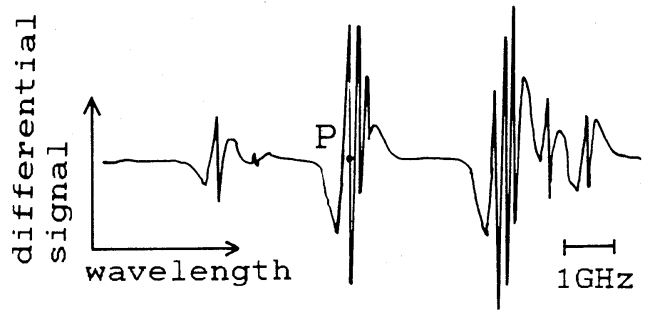

(b)

Fig. 6 Absorption profile (a) and the differential profile (b) of $\mathrm{Rb}^{-} \mathrm{D}_{1}$ saturated absorption spectroscopy.

すものを用いた場合を飽和吸収分光法と呼び， $\mathrm{D}_{1}$ 線の場合, Fig. 6(a)のような吸収波形と Fig. 6 (b)のような微分波形が得られる。Fig. 6 (a)の吸収波形内のくぼみには, 図示したラ ムディップ $(\mathrm{L})$ とクロスオーバーレゾナンス (C) と呼ばれる 2 種類があり，それぞれドップ ラフリーと呼ばれる幅の狭い信号となる ${ }^{12)}$ 。 従って，これらの信号を用いればより良い制御 信号を得ることができ，良い安定度が得られる と考えられる。この波長安定度は, 時間的に変 動する系の安定度の評価によく用いられている アラン分散の平方根 $\sigma$ で表されることが多 い $^{1,19)}$ 。実際にRb-D線を用いた実験では，そ の平均時間が 10 秒のときに, $\sigma=1 \times 10^{-10}$ と $\sigma$ $=4 \times 10^{-11}$ という結果が通常の線形吸収分光法 と飽和吸収分光法のそれぞれに対して得ら $れ^{12)}$ ，飽和吸収分光を用いた場合の方が良い 安定度となっている。 $\mathrm{D}_{2}$ 線を用いた場合にも， 同様に飽和吸収分光を用いてょり良い安定度が 報告されている ${ }^{11,12)}$ 。

\section{4. 高速変調時の波長安定化}

前述したように, 半導体レーザーは直接高速 
変調が可能であるため, 現在, 光ファイバー通 信用光源としてょく用いられている。特にこれ から実用化が期待されているコヒーレント光通 信に半導体レーザーを用いる場合には，変調時 の発振波長の安定化が必要となる。しかし, 変 調時には変調に伴うサイドバンドによる発振幅 の広がりにより，無変調時に得られる波長基準 信号がそのままの特性では得られなくなり，そ の結果, 波長安定化のための制御信号に劣化が 生じ, 安定度が劣化する ${ }^{1)}$ 。

そこで, 安定化のための波長基準信号を得る 方法に工夫を加えた方法がいくつか報告されて いる。波長基準として外部のファブリ・ペロー 共振器を用いた方法には, 変調時のサイドバン ドを使用する方法や ${ }^{20)}$, 非常に大きな変調を 加えた場合の透過光強度の変化の 2 階微分值か ら制御信号を得る方法が報告されている ${ }^{21)}$ 。

原子の吸収線を用いる方法では, Fig. 7 に示 すように，周波数シフトキーイング(FSK)で半 導体レーザーの発振周波数が変調されている場 合に, その周波数変化に応じて透過光強度信号 をスイッチングし, 一方の周波数の透過光強度 信号成分だけを取出し，制御信号を得るために 用いる方法がある。すなわち時間領域のフィル 夕により，そのままではサイドバンドにより広 がった透過光強度信号のスペクトル幅を狭く し，そこから制御信号を得る方法である(同期 受光方式 $)^{2,22)}$ 。この方法で確かに安定度の劣 化は抑制されることが確認されているが, 無変 調時の安定度と比べた場合, より以上の改善は 得られていない。また, 同じ 2 值FSK信号で半 導体レーザーが変調されている場合に, Fig. 8 に示す包絡線検波の原理を利用する方法が報告 されている ${ }^{2,23)}$ 。この方法ではFig. 8 (b)の透 過光強度信号の強い方の信号から, (c)の実線 で示す信号を取出し，そこから (d)の制御信号 を得ている(ピークホールド方式)。この方法で は, 波長安定度の劣化が抑制されるだけではな く, Fig.8 (c) からわかるように, かえって無 変調時よりも幅の狭い波長基準信号が得られ る。その結果, Fig. 8 (d) に示す, より鋭い制

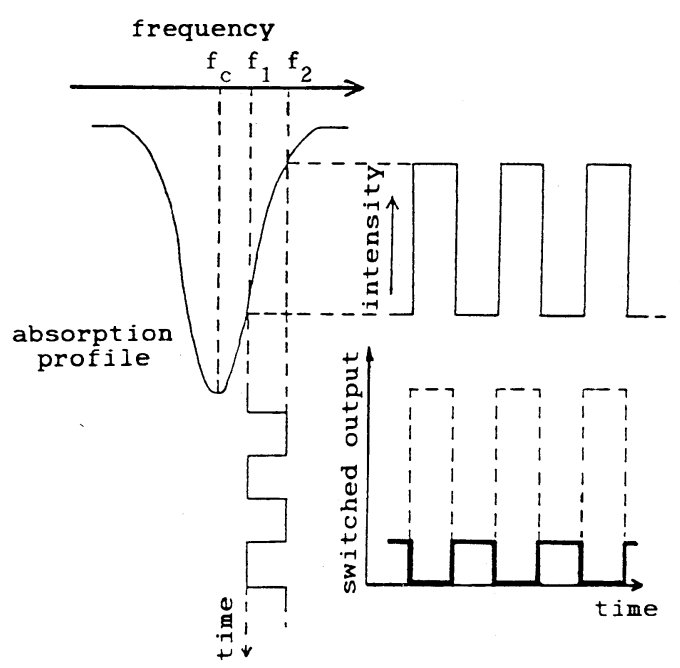

Fig. 7 Principle of a synchronous detection method.

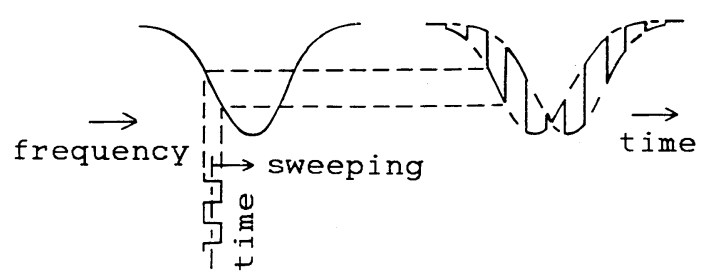

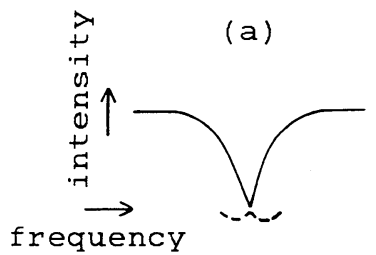

(c) (b)

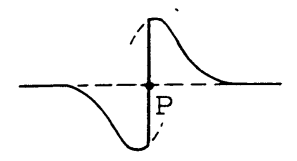

(d)
Fig. 8 Principle of a peak-hold method. (a), Absorption profile and FSK modulation ; (b), Transmitted light intensity signal; (c), Output signal through the peak-hold circuit; (d), Differential profile of the peak-hold method. Point $P$ shows the stabilization point.

御信号が得られる。この制御信号を用いること で, 安定度が無変調時よりも良くなることが報 告されている2)。

\section{5. 無変調の波長安定化}


ファイバージャイロ用光源として使用できる ような発振幅が狭く, かつ波長が安定な半導体 レーザーを得るには，制御信号を得るために注 入電流に微小信号を加えることができない。こ れは, 微小信号による周波数変動そのものが発 振幅を広くするからである。そこでこれまでに 様々な方法が考案されてきた。前述のオフセッ 卜を加える方法なども ${ }^{17,18)}$, 微小信号を加え ない安定化の方法の 1 つであるが，ここではこ れまでに考案されている原子の吸収線を用いた いくつかの方法について述べる。その 1 つは, 外部に設置した超音波光変調器を用いてレー ザー光の周波数を変調した後, 吸収セルを通過 させる方法である ${ }^{24)}$ 。その他に吸収線の磁気 光学効果であるゼーマン効果及びファラデー効 果を用いて吸収線の波長を変調する方法があ る。ゼーマン効果を用いる方法では, 吸収セル に光の進行方向と平行に磁界を加えることによ り, 吸収線がシフトするゼーマン効果を利用し, 半導体レーザーの発振波長を变調する代わり に，吸収線の中心波長を磁界の強度を変えるこ とで変調する方法である。円偏光のレーザー光 を磁界が変調されている吸収セルを通して観測 すると, その透過光強度は半導体レーザーの注 入電流に変調を加えた場合と同様の変化を示 $す^{25)}$ 。特に, 磁界として直流磁界と交流磁界 を重畳した方法では, 安定化点を直流磁界を変 化することにより，掃引できることも報告され ている ${ }^{26)}$ 。またファラデー効果を用いた安定 化では, 直線偏光のレーザー光の, ゼーマン効 果による左右円偏光の光の吸収率の違いによ り，原子にスピン偏極を生じさせ，そこに帰還 光が再び直線偏光で入射した時に生じる光誘起 ファラデー効果による偏光面の回転を偏光板を 通して観測することにより，制御信号を得る方 法がある ${ }^{27)}$ 。今 1 つのファラデー効果を用い た方法としては，Fig. 9のような光学系で，直 流磁界と交流磁界を重畳することで得られる偏 光面の回転を偏光板を通して観測することによ り, 制御信号を得る方法がある。この方法では,

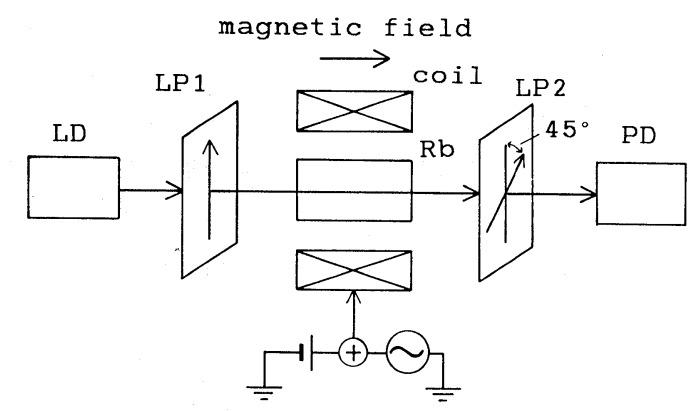

Fig. 9 An example of an optical system using the Faraday effect.

LD, laser diode ; PD, photo diode ; LP1 and LP2, linear polarizer .

偏光板LP1とLP2の偏光方向の間の角度を $45^{\circ} に$ 設定することにより, 偏光面の微小な回転を最 も感度良く透過光強度の変化に変換してい $3^{28)}$ 。この方法でも, 直流磁界を変化させる ことにより，安定化点を掃引できる。

これら無変調での波長安定化では, 従来方式 とほほ同じ安定度が達成されているばかりでは なく，より大きな制御信号を得ることが期待で きるので, 安定度の更なる改善も可能である。 また，その波長安定化点が掃引可能であるとい う点も注目される。

\section{6.おわりに}

原子の吸収線を用いた半導体レーザーの波長 安定化は, 比較的簡単な系で良い安定度を得る ことのできる方法である。

この波長安定化のための波長基準信号は, 通 常の線形吸収分光法よりも，飽和吸収分光法を 用いた場合に，より線幅の狭い信号が得られ， より鋭い制御信号そしてょり良い安定度が達成 されている。

半導体レーザーに直接高速变調が加えられて いる時の波長安定化は，コヒーレント光通信に 必要な技術である。この条件の下での原子の吸 収線を用いた安定化は，包絡線検波の原理を利 用したピークホールド回路を用いることで実現 されて抢り，無変調時よりも良い安定度が高速 変調時に得られている。一方, 波長が安定でか 
つ発振幅の狭い半導体レーザーが必要な応用の ために，注入電流に変調を加えていた従来方式 とは異なり，ゼーマン効果やファラデー効果な どを用いることで，発振波長を変調しない，発 振幅の狭い波長安定化が実現されている。これ らの方法の中には, その安定化点の波長掃引も 大きくはないが可能である方法もある。

\section{参 考 文 献}

1) 佐藤孝, 須貝浩之, 榛葉實：電子通信学会論 文誌 J69-C (1986) 600 .

2）佐藤孝, 小泉春吾, 斉藤敏紀, 榛葉實 : 電子 情報通信学会論文誌 J71-C (1988） 1450 .

3) M.Ohtsu and S.Araki : Appl. Opt. 26 (1987) 464.

4）大津元一，中川賢一：応用物理 58 (1989) 1428.

5) P.P.Sorokin, J.R.Lankard, V.L.Moruzzi and A.Lurio: Appl. Phys. Lett. 15 (1969) 179.

6) T.Endo, T.Yabuzaki, M.Kitano, T.Sato and T. Ogawa : IEEE J. Quantum Electron. QE-13 (1977) 866.

7) M.Ohi : Jpn. J. Appl. Phys. 19 (1980) L541.

8) H.Tsuchida, M.Ohtsu and T.Tako: Jpn. J. Appl. Phys. 21 (1982) L1.

9) G.Herzberg : Atomic Spectra and Atomic Struc. ture (Dover Publications, New York, 1944) Chap.2.

10) H.Tsuchida, M.Ohtsu, T.Tako, N.Kuramochi and N.Oura: Jpn. J. Appl. Phys. 21 (1982) L561.

11) H.Furuta and M.Ohtsu: Appl. Opt. 28 (1989) 3737.

12) T.Sato, M.Niikuni, S.Sato and M.Shimba : Electron. Lett. 24 (1988) 429.
13) T.Yabuzaki, A.Ibaraki, H.Hori, M.Kitano and T. Ogawa: Jpn. J. Appl. Phys. 20 (1981) L451.

14）国立天文台編：理科年表（丸善, 1990） p. 503 .

15) A. M. van der Spek, J. J. L. Mulders and L.W.G.Steenhuysen : J. Opt. Soc. Am. B, 5 (1988) 1478.

16) H.M.Gibbs and R.J.Hull : Phys. Rev. 153 (1967) 132.

17）鳥羽弘, 岩下克, 野須潔, 本杉常治：電子通 信学会昭和60年度総合全国大会 2647 (1985)。

18) K.Kuboki and M.Ohtsu : IEEE J. Quantum Electron. QE-23 (1987) 388.

19) D.W.Allan : Proc. IEEE 54 (1966) 221.

20) C.J. Nielsen and G.Jacobsen : J. Opt. Commun. 4 (1983) 122.

21) H.Tsuchida and Y.Mitsuhashi : Electron. Lett. 23 (1987) 1147.

22) S.Koizumi, T.Sato and M.Shimba : Electron. Lett. 24 (1988) 13.

23）斉藤敏紀，佐藤孝，榛葉實：電子情報通信学 会論文誌 J73-C-I（1990）462。

24）秋山浩二，吉武哲，大手明，古賀保喜，中段 和宏, 大嶋新一：電気学会論文誌 109-C (1989) 22.

25) R.A. Valenzuela, L.J. Cimini, R.W. Wilson, K.C. Reichmann and A.Grot: Electron. Lett. 24 (1988) 725.

26) T.Ikegami, S.Ohshima and M.Ohtsu : Jpn. J. Appl. Phys. 28 (1989) L1839.

27）河村達朗, 渋谷真, 河村研一, 薮崎努, 小川 徹: 日本物理学会第 41 回年会予稿集 $29 \mathrm{a}^{-}$ CC-10 (1986).

28) M. Nakagawa, T. Sato and M. Shimba: Electron. Lett. 25 (1989) 430. 